\title{
Conversion, sorption, and transport of arsenic species in geological media
}

\author{
Q.H. Hu ${ }^{\text {a,* }}$, G.X. Sun ${ }^{\text {b }}$, X.B. Gao ${ }^{\text {c }}$ Y.G. Zhu ${ }^{\text {b }}$ \\ ${ }^{a}$ Department of Earth and Environmental Sciences, The University of Texas at Arlington, Arlington, TX 76019, USA \\ ${ }^{\mathrm{b}}$ Research Center for Eco-environmental Sciences, Chinese Academy of Sciences, Beijing 100085, China \\ ${ }^{c}$ School of Environmental Studies, China University of Geosciences, Wuhan 430074, China
}

\section{A R T I C L E I N F O}

Article history:

Available online 1 February 2012

\begin{abstract}
A B S T R A C T
This work addresses the inter-conversion and sorption of inorganic As species in representative geological media. Through the sensitive quantification of $\mathrm{As}(\mathrm{III})$ and $\mathrm{As}(\mathrm{V})$ with liquid chromatography-inductively coupled plasma-mass spectrometry, and through integrated batch and column approaches, it is shown that natural media can either reduce or oxidize As species. Oxidation of $\operatorname{As}(\mathrm{III})$ to $\mathrm{As}(\mathrm{V})$ is shown in the Hanford sediment, while reduction of $\mathrm{As}(\mathrm{V})$ to $\mathrm{As}(\mathrm{III})$ is shown for the surface soil of Savannah River Site. Overall, the sorption distribution coefficient of $\operatorname{As}(\mathrm{V})$ onto geological media is much larger than that of $\mathrm{As}(\mathrm{III})$, and a reduction of the more sorptive $\mathrm{As}(\mathrm{V})$ to $\mathrm{As}(\mathrm{III})$ will lead to groundwater enrichment with As. Coupled with the different sorption behavior of $\mathrm{As}(\mathrm{III})$ and $\mathrm{As}(\mathrm{V})$, the inter-conversion of these species will strongly affect the geochemical cycling of redox-sensitive As in the subsurface.
\end{abstract}

(c) 2012 Elsevier Ltd. All rights reserved.

\section{Introduction}

Arsenic is a toxic and carcinogenic metalloid found throughout the earth's crust. Well-known high-As groundwater areas occur in Argentina, Chile, Hungary, Mexico, Taiwan, the USA, and, more recently have been found in West Bengal (India) and China in the mid-80s, as well as in Bangladesh and Vietnam in the mid-90s (e.g., Nickson et al., 1998; Nordstrom, 2002; Charlet and Polya, 2006). The concentration of As recommended in drinking water was set at $10 \mu \mathrm{g} / \mathrm{L}$ by the World Health Organization in 1993. The same level was specified by the US Environmental Protection Agency on January 22, 2001. Elevated As concentrations in groundwater have the potential to impact over 100 million people (Smedley and Kinniburgh, 2002; Polya and Charlet, 2009), including 13 million in the USA (O'Day et al., 2004). Up to 30-35 million people in Bangladesh and 6 million in West Bengal are estimated to be exposed to As in drinking water at concentrations above $50 \mu \mathrm{g} / \mathrm{L}$ (BEG, 2001; Charlet and Polya, 2006). The fact that millions of people drink As-tainted well water in SE Asia has been characterized as the largest mass poisoning in history.

Arsenic is present in a variety of inorganic and organic chemical forms in the environment (Cullen and Reimer, 1989; NRC, 1999). It has at least four oxidation states: $-3,0,+3$ and +5 . The most common forms of As present in groundwater are the inorganic forms of $\mathrm{As}(\mathrm{V})$ and $\mathrm{As}(\mathrm{III})$. Concentrations of organic As in groundwater are generally low or negligible (e.g., Chen et al., 1995; Fendorf and Kocar, 2009). The pentavalent forms of $\mathrm{As}_{3} \mathrm{H}_{3} \mathrm{AsO}_{4}$ (aq), $\mathrm{H}_{2} \mathrm{AsO}_{4}^{-}$,

\footnotetext{
* Corresponding author. Tel.: +1 8172725398; fax: +1 8172722628 .

E-mail address: maxhu@uta.edu (Q.H. Hu).
}

$\mathrm{HAsO}_{4}^{2-}$ and $\mathrm{AsO}_{4}^{3-}$ are typically predominant in oxidizing environments, and the trivalent $\mathrm{H}_{3} \mathrm{AsO}_{3}$ (aq), $\mathrm{H}_{2} \mathrm{AsO}_{3}^{-}, \mathrm{HAsO}_{3}^{2-}$ and $\mathrm{AsO}_{3}^{3-}$ are mostly found in reducing environments with oxidation potentials (Eh) of about $+300 \mathrm{mV}$ at $\mathrm{pH} 4$ to $-200 \mathrm{mV}$ at $\mathrm{pH} 9$ (Inskeep et al., 2002). The degree of protonation of As(V) and As(III) is largely determined by solution $\mathrm{pH}$. Aqueous As species in most natural waters (with $\mathrm{pH} 4-10$ ) are the neutral species $\mathrm{H}_{3} \mathrm{AsO}_{3}$ for $\mathrm{As}(\mathrm{III})$, and $\mathrm{H}_{2} \mathrm{AsO}_{4}^{-}$and $\mathrm{HAsO}_{4}^{2-}$ for $\mathrm{As}(\mathrm{V})$ (Cullen and Reimer, 1989; Bissen and Frimmel, 2003; Fendorf and Kocar, 2009).

Arsenate is known to sorb onto many mineral phases, thus exhibiting a lower mobility in the environment. However, arsenite tends to sorb less strongly to the key mineral phases, although the relative strength of sorption depends upon a range of factors, including As concentration, pH, and water chemistry (Onken and Adriano, 1997; O'Reilly et al., 2001; Dixit and Hering, 2003; Williams et al., 2003; Masue et al., 2007; Saeki, 2008; Tufano and Fendorf, 2008; Choi et al., 2009). Nevertheless, the reduction of sorbed $\mathrm{As}(\mathrm{V})$ results in the mobilization of the more mobile and bioavailable $\mathrm{As}(\mathrm{III})$, which is also more (twice to three times) toxic than $\mathrm{As}(\mathrm{V})$ compounds (Vaughan, 2006). Iron oxides play a pivotal role in the biogeochemical behavior of As, and provide an ubiquitous As-trapping pool in soils and sediments (Belzile and Tessier, 1990; Cancès et al., 2005; Ackermann et al., 2008). Hydrous ferric oxides (e.g., ferrihydrite) are the most reactive soil components with respect to As sorption and can take up hundreds of $\mathrm{mg} / \mathrm{kg}$ As, either as As(III) or As(V) (Goldberg, 2002). Acidic conditions favor the protonation of mineral surfaces and the adsorption of $\mathrm{As}(\mathrm{V})$ forms $\left(\mathrm{H}_{2} \mathrm{AsO}_{4}^{-}\right.$or $\left.\mathrm{HAsO}_{4}^{2-}\right)$, while $\mathrm{As}(\mathrm{III})$ remains soluble in such conditions as arsenious acid $\left(\mathrm{H}_{3} \mathrm{AsO}_{3}\right)$. Under alkaline conditions, $\mathrm{As}(\mathrm{III})$ adsorbs preferentially to $\mathrm{As}(\mathrm{V})$ on Fe oxide surfaces. Near 
neutral to alkaline $\mathrm{pH}$ (i.e., closer to the $\mathrm{pK}_{a}$ of $\mathrm{H}_{3} \mathrm{AsO}_{3}$ at 9.2), arsenate and arsenite both adsorb with similar efficiency onto the surfaces of hydrous ferric oxides and crystalline Fe oxides via the formation of strong inner-sphere surface complexes (Morin and Calas, 2006).

The objectives of this investigation were to study the inter-conversion, sorption and transport of $\mathrm{As}(\mathrm{V})$ and $\mathrm{As}(\mathrm{III})$ in a range of geologic materials having different physical and chemical properties. The primary analytical tool used in the study was liquid chromatography-inductively coupled plasma-mass spectrometry (LCICP-MS); both batch and column experiments were carried out in an integrated way. The interdependent processes of species interconversion, sorption, and transport are of fundamental importance in understanding the biogeochemical behavior and groundwater enrichment potential of As.

\section{Materials and methods}

\subsection{Materials}

Seven sediment or soil samples were used in the study. Four were taken from nuclear facilities of the US Department of Energy. In addition, two sediment samples were collected from the Datong Basin of China, and a surface soil sample was collected from the Faridpur area of Bangladesh; in both of these areas, high As concentrations are found in groundwater used for drinking.

The four samples from nuclear facilities included three uncontaminated samples from the Savannah River Site (SRS) in South Carolina, and one from the Hanford Site in Washington. The SRS samples were collected at three different depths, representing the surface soil, subsoil and aquifer environments. All four nuclear facility samples were previously used in conversion and sorption studies of I species, as reported in Hu et al. (2005). The SRS and Hanford locations represent a significant contrast in geologic and climatologic conditions. The SRS has a humid subtropical climate with annual rainfall of $91-112 \mathrm{~cm}$, and is characterized geologically by weathered soils containing high amounts of Fe oxides. In contrast, the Hanford Site is located in an arid region with an average annual rainfall of only $16 \mathrm{~cm}$; its geology is characterized by bedded alluvial plain deposits with numerous sands and gravels. Further variation in geologic properties occurs among the three SRS samples themselves, owing to the different environments which they represent. Properties of the four samples from the Department of Energy sources were measured by standard procedures, as reported by Hu et al. (2005); the clay mineralogy of these samples is presented in Table 1.

The samples collected from the Datong Basin of China and from the Faridpur area of Bangladesh provided additional variation in sample character. These two areas represent sharply contrasting environments, particularly with respect to organic matter, clay mineralogy texture, and other hydrogeochemical characteristics. For example, the Datong Basin is located at $950-1100 \mathrm{~m}$ above sea level, has a continental monsoon climate, and is moderately arid. The sediments of the basin originate from alluvial and lacus- trine deposition of fine sand and clay; the water table ranges from 5 to $60 \mathrm{~m}$ below the surface. High As concentrations are found between the depths of $15 \mathrm{~m}$ and $60 \mathrm{~m}$. From two borehole samples collected at depths of 24 and $50 \mathrm{~m}$, the groundwater has a pH value $>8.2$ (Xie et al., 2008; Yang, 2008). The aquifers contain less than $0.2 \%$ organic matter, and, based on X-ray diffraction analyses, the mineral composition of the aquifers is primarily quartz, with lesser amounts of illite, calcite, smectite, and biotite (Guo et al., 2003; Yang, 2008). The two Datong sediment samples studied in this work were collected from depths of 24.1-24.5 m (DY-12) and 50.2-50.6 $\mathrm{m}$ (DY-22) below ground surface (Table 1).

In contrast, the Faridpur district of the Dhaka Division is located in the central area of Bangladesh, at an elevation of less than $12 \mathrm{~m}$ above sea level, in an area of tropical climate. A mild winter extends from October to March, a hot and humid summer from March to June, and a warm and humid monsoon season from June to October. Most of the annual rainfall occurs in the monsoon season, and can cause flooding as high as $5 \mathrm{~m}$, which in turn leads to seasonal fluctuation of the water table and a dynamic hydrologic regime. The soils of the Ganges River floodplains in Faridpur are enriched with As because the Holocene sediments deposited in this plain have a total As content as high as $60 \mathrm{mg} / \mathrm{kg}$. Soils of Faridpur are alkaline in nature ( $\mathrm{pH} 7.5-8.5$ ), and have a silty clay to clay texture, with montmorillonite as the dominant clay mineral. Organic matter content is $1.5-2.5 \%$. A surface soil sample in Faridpur was provided by Rafiqul Islamin Bangladesh Agricultural University (Table 1). Faridpur was one of the three Special Study Areas in a detailed investigation conducted by the British Geological Survey, and was identified as one of three areas having the highest As concentration in Bangladesh (BGS, 2001). Over 500 groundwater samples were collected in Faridpur Municipality. It was reported that around $70 \%$ of the samples were enriched with As (i.e., $>50 \mu \mathrm{g} / \mathrm{L}$ ) and that the results displayed a considerable spatial variability.

In summary, the wide range of hydrogeologic conditions and environments represented in both the domestic and overseas sediments used in this study provided an opportunity to examine the influences of organic matter, clay mineralogy, soil pH, texture and other factors on the conversion and sorption of As species. Stock standard solutions of $\mathrm{As}(\mathrm{III}), \mathrm{As}(\mathrm{V})$, monosodium acid methane arsonate (MMA), and sodium cacodylate (dimethylarsenic acid, DMA) were prepared by dissolving each chemical compound in autoclaved ultrapure water at a concentration of $100 \mathrm{mg} / \mathrm{L}$ (As content) in a separate autoclaved amber glass bottle. Sodium arsenite and MMA were obtained from J.T. Baker (Phillipsburg, NJ), while sodium arsenate dibasic and DMA were purchased from Alfa Aesar (Ward Hill, MA) and Sigma-Aldrich (St. Louis, MO), respectively. All solutions were prepared using purified DI water (Milli-Q Ultrapure Water Purification System, Millipore).

\subsection{Batch and column tests}

To initiate the investigation, a series of batch tests were conducted. In each test, a solution of $\mathrm{As}(\mathrm{V})$ or $\mathrm{As}(\mathrm{III})$ was placed in contact with one of the seven sediments. The tests were carried out in

Table 1

Information and properties of samples used in this work.

\begin{tabular}{|c|c|c|c|c|c|c|c|}
\hline Sample & Hanford sediment & $\begin{array}{l}\text { SRS surface } \\
\text { soil }\end{array}$ & SRS subsoil & SRS aquifer & Datong DY-12 & Datong DY-22 & Faridspur \\
\hline Description & $\begin{array}{l}\text { Composite of core samples } \\
9-12 \text { m below surface }\end{array}$ & Surface soil & $\begin{array}{l}\text { Composite of sediment } \\
12 \mathrm{~m} \text { below surface }\end{array}$ & Aquifer & $\begin{array}{l}24.1-24.5 \mathrm{~m} \\
\text { below surface }\end{array}$ & $\begin{array}{l}50.2-50.6 \mathrm{~m} \\
\text { below surface }\end{array}$ & Surface soil \\
\hline Location & Richland, WA & Aiken, SC & Aiken, SC & Aiken, SC & Datong, China & Datong, China & $\begin{array}{l}\text { Faridspur, } \\
\text { Bangladesh }\end{array}$ \\
\hline Clay mineralogy & Smectite, chlorite, mica & HIV, kaolinite & Kaolinite, goethite, HIV & $\begin{array}{l}\text { Goethite, } \\
\text { kaolinite, I }\end{array}$ & Illite, chlorite & Illite, chlorite & Montmorillonite \\
\hline
\end{tabular}

HIV: hydroxyl interlayered vermiculite; I: illite or weathered mica. 
accordance with ASTM method D161687 (1998), except that a solution to solid ratio of $4: 1$ was employed instead of the $20: 1$ ratio specified in the ASTM method (A ratio of 20:1 is unrealistically high when compared to the ratios commonly encountered under field conditions). For each sediment, triplicate blank treatments were conducted (adding only $1 \mathrm{mM} \mathrm{Ca}\left(\mathrm{NO}_{3}\right)_{2}$ as the electrolyte solution); triplicate treatments of either $\mathrm{As}(\mathrm{V})$ or $\mathrm{As}(\mathrm{III})$ at the concentration of $1 \mathrm{mg} / \mathrm{L}\left(1.3 \times 10^{-5} \mathrm{M}\right)$. Instead of the commonly used electrolyte $\mathrm{CaCl}_{2}, \mathrm{Ca}\left(\mathrm{NO}_{3}\right)_{2}$ was used, to prevent the interference of ${ }^{40} \mathrm{Ar}{ }^{35} \mathrm{Cl}$ in the ICP-MS analyses of ${ }^{75} \mathrm{As}$. Control samples, with $\mathrm{As}(\mathrm{V})$ or $\mathrm{As}(\mathrm{III})$ solution but no sediment, were also included to discern the potential conversion of $\mathrm{As}(\mathrm{V})$ and $\mathrm{As}(\mathrm{III})$. After 24-h equilibration, the mixture was centrifuged at $6000 \mathrm{rpm}$ for $30 \mathrm{~min}$ and then vacuum filtered through $0.25 \mu \mathrm{m}$ Supor membranes (Pall Corporation, Ann Arbor, MI). The liquid samples were analyzed for $\mathrm{pH}$ with a standard glass electrode, and for the concentration of As species using LC-ICP-MS.

Two column transport tests were then conducted to further study the dynamic behavior of inter-conversion of As species. A glass column from Omnifit in Boonton, $\mathrm{NJ}$ (1.5- $\mathrm{cm}$ inner diameter, $10.0-\mathrm{cm}$ long) was incrementally packed with either Hanford sediment or SRS surface soil to obtain a uniform bulk density. To achieve full liquid saturation, the packed column was first evacuated by pulling vacuum and then by introduction of electrolyte solution, $1 \mathrm{mM} \mathrm{Ca}\left(\mathrm{NO}_{3}\right)_{2}$; no visible air pockets were observed. Then approximately 100 column pore volumes of $1 \mathrm{mM} \mathrm{Ca}\left(\mathrm{NO}_{3}\right)_{2}$ were pumped through the column prior to the transport study.

The methods employed for the column studies were similar to those used in previous experiments (e.g., $\mathrm{Hu}$ and Brusseau, 1996). A HPLC pump (Model 301 from Alltech Associates Inc. Deerfield, IL) was connected to the column, and a three-way valve placed in-line to facilitate switching between solutions with and without the tracer of interest. Depending on the batch sorption results of observed As reduction or oxidation, a single As species [either $\mathrm{As}(\mathrm{V})$ or $\mathrm{As}(\mathrm{III})$ with an initial concentration of about $600 \mu \mathrm{g} / \mathrm{L}$, prepared in $1 \mathrm{mM} \mathrm{Ca}\left(\mathrm{NO}_{3}\right)_{2}$ ] was injected into the column to study As transport behavior and species conversion. For example, the SRS surface soil column was injected with As(V) solution under a flow rate of $0.1 \mathrm{~mL} / \mathrm{min}$, with a corresponding porewater velocity of $10.3 \mathrm{~cm} / \mathrm{h}$, for $103 \mathrm{~h}$ and then switched to $1 \mathrm{mM} \mathrm{Ca}\left(\mathrm{NO}_{3}\right)_{2}$ for flushing injected As solution for another $360 \mathrm{~h}$. The column effluent solution was periodically (15 min initially, which was increased to 20,45 and $80 \mathrm{~min}$ ) collected with a fraction collector (Spectra/Chrom CF-1, Spectrum Chromatography, Houston, TX). The liquid sample was analyzed for arsenic species using LC-ICP-MS, and the total concentration of other major and trace elements with ICP-MS.

\subsection{Analyses of arsenic species and total elemental concentration}

An advanced analytical method, the LC-ICP-MS method, was used for As speciation studies, following the isocratic method published in Reuter et al. (2003), for sensitive and simultaneous analyses of As species in aqueous samples. Briefly, the LC system consisted of a Perkin Elmer Series 200 Quaternary Pump and a Series 200 Autosampler (Perkin Elmer/SCIEX, Sheldon, CT) with a Hamilton PRP-X100 $(4.1 \mathrm{~mm} \times 250 \mathrm{~mm}, 10 \mu \mathrm{m})$ anion exchange column and a guard column (Sparks, NV). Separation conditions included the following: mobile phase of $10 \mathrm{mM}$ ammonium nitrate and $10 \mathrm{mM}$ ammonium phosphate (dibasic) at $\mathrm{pH}$ of 9.4 (adjusted with ammonium hydroxide), flow rate $1.5 \mathrm{~mL} / \mathrm{min}$, and sample injection volume $100 \mu \mathrm{L}$. The effluent from the $\mathrm{LC}$ column was directly connected, via $60 \mathrm{~cm}$ of trifluoroacetic acid capillary tubing (1.6 mm o.d. $\times 0.5 \mathrm{~mm}$ i.d.), to the nebulizer of PerkinElmer/SCIEX ELAN DRC II (Sheldon, CT) for the determination of As concentration. The sample introduction system components of the ICP-MS consisted of a cyclonic spray chamber, a Meinhard ${ }^{\circledR}$ type A nebulizer, and Pt cones.

Each individual As species was prepared to obtain the retention time from HPLC separation for peak identification. With a run time of less than 6 min to separate four common As species, the retention times for As(III), DMA, MMA, and As(V) were 1.8, 2.2, 3.5, and $5.6 \mathrm{~min}$, respectively. The detection limits for As(III), DMA, MMA, and $\mathrm{As}(\mathrm{V})$ were measured to be $0.12,0.12,0.19$, and $0.14 \mu \mathrm{g} / \mathrm{L}$, respectively. However, working standard solutions, in the range of $0.001-1 \mathrm{mg} / \mathrm{L}$ As, were prepared by diluting the stock standard solution of DMA only (Sun et al. 2008), because one of the major purposes of this study was to identify the potential inter-conversion of $\mathrm{As}(\mathrm{V})$ and $\mathrm{As}(\mathrm{III})$.

In addition to LC-ICP-MS analyses of As species, total elemental concentrations in the column effluents were determined by ICP-MS to measure elements of interest ( $\mathrm{As}, \mathrm{Fe}, \mathrm{Mn}, \mathrm{K}, \mathrm{Na}, \mathrm{Ca}, \mathrm{Mg}$ ). To measure Fe concentrations, in order to evaluate the effect of Fe in mediating As conversion, the capabilities of Dynamic Reaction Cell (DRC) were used; ammonium was used as the reaction gas to minimize the polyatomic interference of ${ }^{40} \mathrm{Ar}^{16} \mathrm{O}$ on the analyses of ${ }^{56} \mathrm{Fe}$ (Vanhaecke et al., 2002; Kawabata and Kishi, 2003; D'llio et al., 2006).

\section{Results and discussion}

\subsection{Standard preparation and analyses of arsenic species}

Each of the four common As species was prepared as a single standard. Fig. 1 shows the separation and sensitive determination of these four As species, in triplicate measurements, as determined in less than 6 min. While $\mathrm{As}(\mathrm{III})$ and $\mathrm{As}(\mathrm{V})$ commonly exist in geological systems, both DMA and MMA are present in biological systems and some surface soils. The simultaneous separation and quantification of these As species provided a very useful tool for investigating the inter-conversion of As species in this study.

The collection and preservation of high-quality samples are critical steps in speciation studies (Polya et al., 2003; Gault et al., 2005). Based on results from a series of experiments, McCleskey et al. (2004) reported that water samples that may contain As(III) should be preserved with $\mathrm{HCl}$ to $\mathrm{pH}$ values below 2 , chilled at $4{ }^{\circ} \mathrm{C}$, and stored in the dark. Overall, filtration through $0.1 \mu \mathrm{m}$ compared with $0.45 \mu \mathrm{m}$ filters did not affect the preservation of As(III). Collecting and filtering in a $\mathrm{N}_{2}$ atmosphere was not necessary for As(III) preservation (McCleskey et al., 2004). However, samples preserved with $\mathrm{HCl}$ may interfere with the determination of As by an ICP-MS method because of the ${ }^{40} \mathrm{Ar}^{35} \mathrm{Cl}^{+}$molecular interference on monoisotopic ${ }^{75} \mathrm{As}^{+}$, unless a collision cell is used to eliminate the interference. Preserving samples with ethylenediamine tetraacetic acid (EDTA)

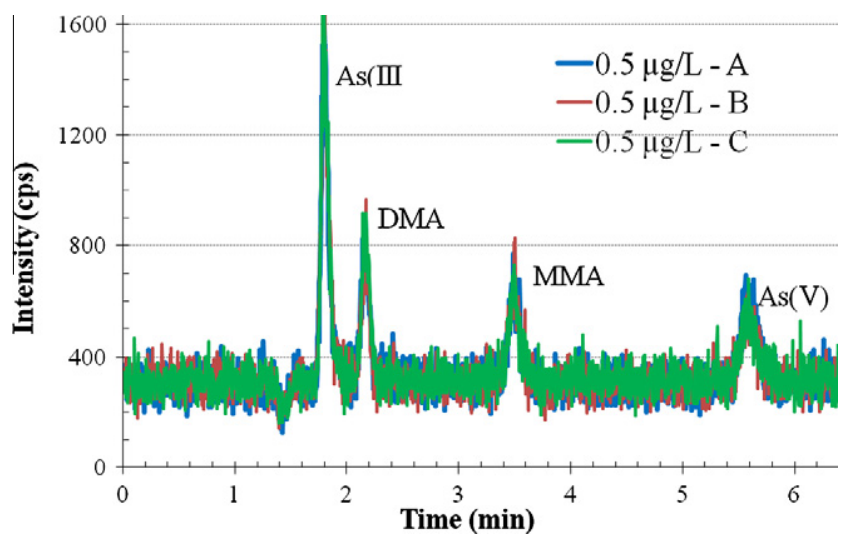

Fig. 1. Separation and quantification of four As species at the concentration of $0.5 \mu \mathrm{g} / \mathrm{L}$. 
is preferred when determining $\mathrm{As}(\mathrm{III}), \mathrm{As}(\mathrm{V}), \mathrm{MMA}$, and DMA by chromatographic separation and detection by ICP-MS (Garbarino et al., 2002); EDTA chelates Fe and prevents photochemical, oxidation, and precipitation reactions.

The early results from monitoring each As species standard over time indicated a significant conversion of $\mathrm{As}(\mathrm{V})$ to $\mathrm{As}(\mathrm{III})$ in $\mathrm{DI}$ water, but showed negligible oxidation of $\mathrm{As}(\mathrm{III})$ to $\mathrm{As}(\mathrm{V})$ (Fig. 2a). This differs from the results of some other studies in which the focus was primarily on the oxidation of $\mathrm{As}(\mathrm{III})$ to $\mathrm{As}(\mathrm{V})$ (Bednar et al., 2002; McCleskey et al., 2004). However, Gallagher et al. (2001) reported the reduction of $\mathrm{As}(\mathrm{V})$ to $\mathrm{As}(\mathrm{III})$, which was probably caused by microorganisms accumulated from the organic resin in the DI purification system. Consequently, in the present study the DI water was autoclaved, as well as the amber glass bottles, in the preparation of individual As species standards at about $1000 \mu \mathrm{g} / \mathrm{L}$, and the concentration change monitored over nearly seven months. For each As species standard, all four As species [As(III), As(V), MMA, and DMA] were determined by LC-ICP-MS. After adopting these procedures, no consistent inter-conversion among the four As species were observed, even after nearly 6 months (Fig. 2b), although some variability was apparent. The standards prepared according to these revised preservation procedures were used in the subsequent batch and column experiments.

\subsection{Sorption and conversion of inorganic arsenic species}

Batch sorption experiments were carried out to examine the inter-conversion of inorganic $\mathrm{As}(\mathrm{V})$ and $\mathrm{As}(\mathrm{III})$. As discussed in

(a)
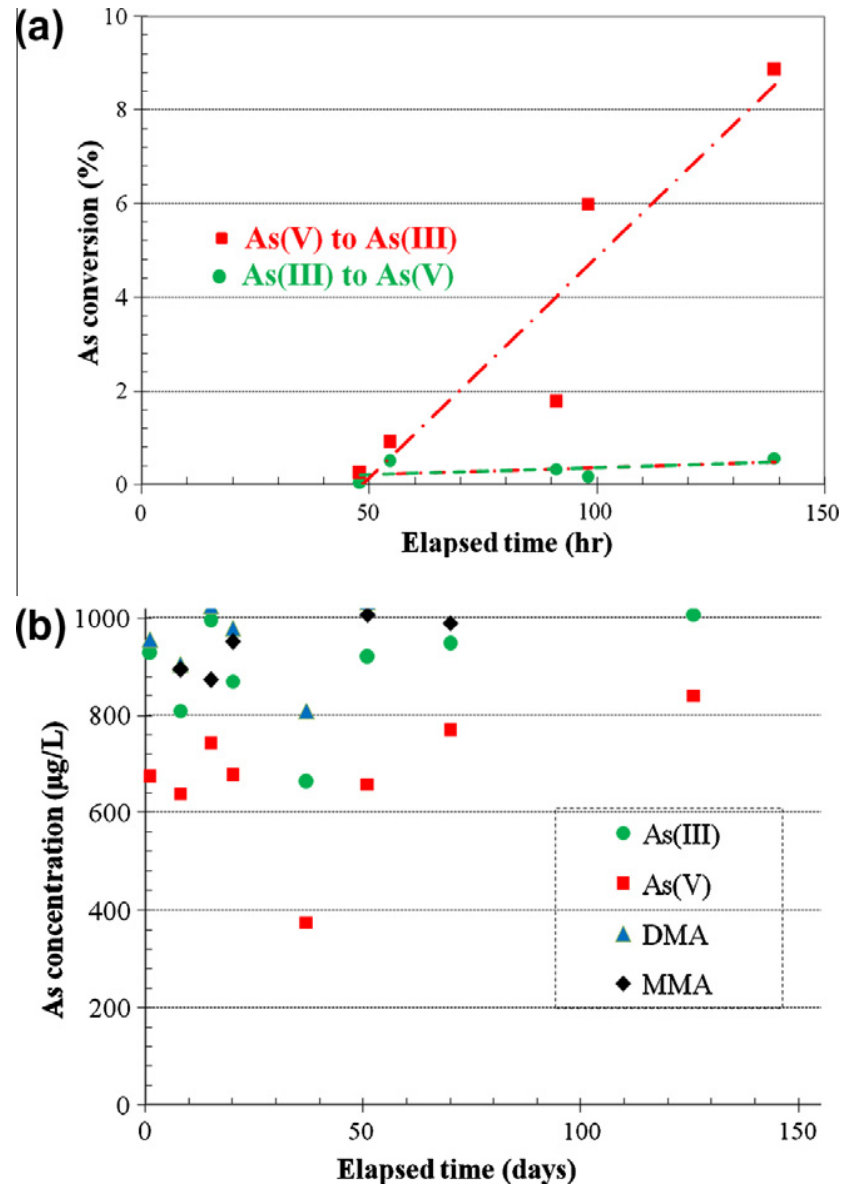

Fig. 2. (a) Conversion of $\mathrm{As}(\mathrm{V})$ to $\mathrm{As}(\mathrm{III})$ over time in a standard prepared with $\mathrm{DI}$ water. (b) Stability test of As species standards prepared in autoclaved DI water and amber-glass bottles; a sample was taken out over time from each As species source bottle prepared at about $1000 \mu \mathrm{g} / \mathrm{L}$ concentration.
Section 2, four treatments were conducted, including blank, control, $\mathrm{As}(\mathrm{V})$, and $\mathrm{As}(\mathrm{III})$. The sorption and inter-conversion of $\mathrm{As}(\mathrm{III})$ and $\mathrm{As}(\mathrm{V})$ were examined in five sediments and two surface soils with different physico-chemical properties (Table 1). In these batch sorption tests, $4 \mathrm{~mL} \mathrm{As(III)}$ or $\mathrm{As}(\mathrm{V})$ solutions containing about $300 \mu \mathrm{g} / \mathrm{L}$ were mixed with $1 \mathrm{~g}$ of sediment for $24 \mathrm{~h}$, and the filtered supernatant was analyzed for both $\mathrm{As}(\mathrm{III})$ and $\mathrm{As}(\mathrm{V})$ using LC-ICP-MS.

Fig. 3 presents the chromatography results of batch experiments for Hanford sediment and SRS surface soil. Fig. 3a shows some oxidation of $\mathrm{As}(\mathrm{III})$ to $\mathrm{As}(\mathrm{V})$ in Hanford sediment, where $\mathrm{As}(\mathrm{III})$ treatment produces a higher $\mathrm{As}(\mathrm{V})$ peak than the blank treatment, indicating the inter-conversion of $\mathrm{As}(\mathrm{III})$ to $\mathrm{As}(\mathrm{V})$ after its contact with the Hanford sediment. In contrast, Fig. 3b exhibits the reduction of $\mathrm{As}(\mathrm{V})$ to $\mathrm{As}(\mathrm{III})$ in SRS surface soil, wherein $\mathrm{As}(\mathrm{V})$ treatment yields a considerable As(III) peak.

At the end of the 24-h equilibration time, the aqueous concentration $C_{w}$ was measured for As species, and the sorbed concentration $C_{s}\left(\mathrm{mg} \mathrm{kg}^{-1}\right)$ was calculated from the difference in initial and final aqueous concentration $C_{w}$. The sorption coefficient $K_{d}\left(\mathrm{~L} \mathrm{~kg}^{-1}\right)$ was calculated as the ratio of $C_{s}$ over $C_{w}$ to quantify the sorption of As onto the solid phases. If there is inter-conversion between $\mathrm{As}(\mathrm{V})$ and $\mathrm{As}(\mathrm{III})$, the apparent distribution coefficient $\left(K_{d}\right)$ values of either $\mathrm{As}(\mathrm{III})$ or $\mathrm{As}(\mathrm{V})$ include the concentration decrease both from sorption onto solid phases and from the possible inter-conversion (Table 2). The inter-conversion can only be assessed from the simultaneous measurements of As species using LC-ICP-MS, to determine if both $\mathrm{As}(\mathrm{III})$ and $\mathrm{As}(\mathrm{V})$ are present in the solution
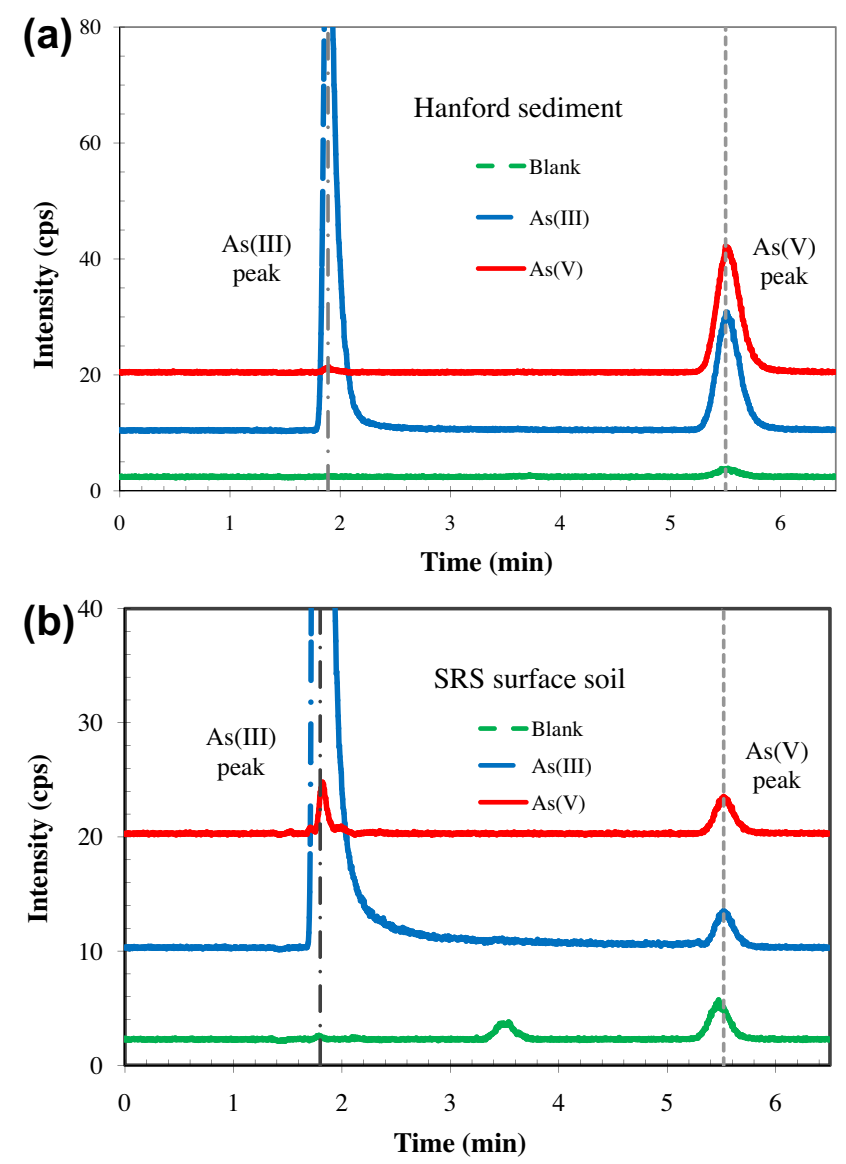

Fig. 3. LC chromatograms with ICP-MS detection for the (a) Hanford sediment and (b) SRS surface soil with three treatments (blank: $1 \mathrm{mM} \mathrm{Ca}\left(\mathrm{NO}_{3}\right)_{2}$ electrolyte solution; $\mathrm{As}(\mathrm{V}): 1.3 \times 10^{-5} \mathrm{M} \mathrm{As}(\mathrm{V})$ in the electrolyte solution; and $\mathrm{As}(\mathrm{III})$ : $1.3 \times 10^{-5} \mathrm{M} \mathrm{As}(\mathrm{III})$ in the electrolyte solution. 
phase, when only either $\mathrm{As}(\mathrm{III})$ or $\mathrm{As}(\mathrm{V})$ was applied to the solid sample. Note that only the As species in aqueous solution were measured; either $\mathrm{As}(\mathrm{III})$ or $\mathrm{As}(\mathrm{V})$ produced from inter-conversion can be sorbed onto the solid, to different extents. This work focused on the inter-conversion and sorption of As species, but not on the precise conversion rate, which would require the independent measurement of As species on the solid phases.

For the Hanford sediment, a noticeable $(2.5 \pm 0.28 \%)$ conversion of applied As(III) to As(V) was observed (Table 2). The Hanford sediment contains smectite, chlorite and mica as the dominant clay mineralogy. After adsorption onto clay minerals such as illite and kaolinite in the pH range of 4-10, Manning and Goldberg (1997) reported the oxidation of $\mathrm{As}(\mathrm{III})$ to $\mathrm{As}(\mathrm{V})$.

In contrast to the As oxidation in the Hanford sediment, a reduction rate of $4.5 \pm 0.46 \%$ from $\mathrm{As}(\mathrm{V})$ to $\mathrm{As}(\mathrm{III})$ was measured in SRS surface soil. The reduction of $\mathrm{IO}_{3}^{-}$to $\mathrm{I}^{-}$was also reported in this surface soil (Hu et al., 2005), probably due to biotic or abiotic processes mediated by structural Fe present in the clay minerals of the sample. The most abundant natural reductants are soil clay minerals containing reduced forms of Fe and S (Stucki et al., 1996).

Fendorf and Kocar (2009) summarized that, in general, As(V) binds extensively and strongly to most mineral constituents of soils and sediments, which include Fe and Al oxides, Al hydroxides, aluminosilicate clay minerals, Mn oxides (e.g., birnessite), and organic matter. In contrast, the retention of $\mathrm{As}(\mathrm{III})$ is more dependent on specific soil chemical conditions, particularly $\mathrm{pH}$ and mineralogy. Arsenic(III) exhibits a limited affinity for most soil minerals with the exception of Fe (hydr)oxides.

Values of $K_{d}$ provide a direct indication of the interactions of a solute with the solid materials, with the solute mobility more retarded at larger $K_{d}$ values. As summarized by Sharma and Sohn (2009), Fe oxides and hydroxides of a variety of compositions and degrees of crystallinity are virtually ubiquitous in natural aqueous systems, and are known to play a major role in As sorption. Clays and oxides/oxyhydroxides of $\mathrm{Al}$ and $\mathrm{Mn}$ are also important adsorbents of As, especially in Fe deficient systems. In addition, the oxidation state of As and the $\mathrm{pH}$ of the system are crucial to adsorptive behavior, as is the presence of competing ions.

Iron (hydr)oxides, clay mineralogy, and $\mathrm{pH}$ appear to have had a combined effect on the extent of $\mathrm{As}(\mathrm{III})$ and $\mathrm{As}(\mathrm{V})$ adsorption in the tested samples of this study. The Hanford sediment sample shows low and comparable apparent $K_{d}$ values for $\mathrm{As}(\mathrm{III})$ and $\mathrm{As}(\mathrm{V})$. In addition, Faridpur soil shows similar sorption for these two inorganic As species, though its sorption magnitude is much larger than that of the Hanford sediment. While most adsorption studies have shown that $\mathrm{As}(\mathrm{V})$ adsorbs more strongly than does $\mathrm{As}(\mathrm{III})$, Lenoble et al. (2002) reported that goethite and amorphous Fe hydroxide show higher adsorptive capacities for As(III) than for $\mathrm{As}(\mathrm{V})$ at $\mathrm{pH}$ values below 9.

Samples from the three depths at the Savannah River Site, which represent surface soil, subsoil, and aquifer, show a much higher sorption capacity for $\mathrm{As}(\mathrm{V})$ than for $\mathrm{As}(\mathrm{III})$. The same is true for the two samples from the Datong Basin of Shanxi in China
(Datong DY-12 and DY-22), which were also collected from different depths. The results are consistent with those of numerous reports citing stronger sorption of $\mathrm{As}(\mathrm{V})$ than $\mathrm{As}(\mathrm{III})$ in minerals and soils at the concentration ranges typical of natural systems (Belzile and Tessier, 1990; Goldberg, 2002; Dixit and Hering, 2003, 2006; Cancès et al., 2005; Ackermann et al., 2008; Tufano and Fendorf, 2008); this is specifically true at $\mathrm{pH}<7$. At higher $\mathrm{pH}$ values, the extent of $\mathrm{As}(\mathrm{III})$ and $\mathrm{As}(\mathrm{V})$ adsorption is more similar (Sharma and Sohn, 2009).

\subsection{Conversion and transport of arsenic species}

From the batch test with SRS surface soil, some applied As(V) was found to be converted to As(III), which has a much smaller apparent $K_{d}$ value (Table 1 ), implying that a column transport test could be utilized to observe the breakthrough curve of As(III) converted from applied $A s(V)$. This is indeed observed in Fig. 4, for a pulse injection of about $600 \mu \mathrm{g} / \mathrm{L} \mathrm{As}(\mathrm{V})$ in SRS surface soil. A small, but measurable, amount of $\mathrm{As}(\mathrm{III})$ was detected in the column effluent, though only $\mathrm{As}(\mathrm{V})$ was introduced. In addition, the total As concentration as measured by ICP-MS is similar to the sum of $\mathrm{As}(\mathrm{III})$ and $\mathrm{As}(\mathrm{V})$ determined by LC-ICP-MS (Fig. 4), which shows the validity of both analytical methods.

Most of the injected $\mathrm{As}(\mathrm{V})$ did not break through in the column transport tests, which was expected given the large $K_{d}$ value of $\mathrm{As}(\mathrm{V})$ in SRS surface soil. However, along with As(III), a smaller amount of $\mathrm{As}(\mathrm{V})$ was observed to be present more or less coinciding with $\mathrm{As}(\mathrm{III})$. This was not expected because $\mathrm{As}(\mathrm{V})$ should have a much larger sorptive retardation than As(III) in SRS surface soil (Table 1) and should, therefore, be detected much later than As(III) even if it breaks through. The simultaneous breakthrough of As(III) and $\mathrm{As}(\mathrm{V})$ in Fig. 4 might be related to the question of whether the reduction of $\mathrm{As}(\mathrm{V})$ occurs in the solid or aqueous phases; further research on this issue may help the understanding of $\mathrm{As}(\mathrm{V})$ reduction and rapid migration of As(III) in the subsurface.

Along with the As species, aqueous concentrations of soluble $\mathrm{Mn}$ (e.g., $\mathrm{Mn}^{2+}$ ) and $\mathrm{Fe}$ (aqueous $\mathrm{Fe}^{2+}$ and colloidal $\mathrm{Fe}$ forms) in the column effluents were also monitored using ICP-MS with the DRC capability. The results showed that the $\mathrm{Fe}(\mathrm{III}) / \mathrm{Fe}(\mathrm{II})$ redox couple was not triggered in the above test of $\mathrm{As}(\mathrm{V})$ transport in SRS surface soil, as indicated by the steady soluble Fe concentration. However, the $\mathrm{Mn}(\mathrm{VI}) / \mathrm{Mn}(\mathrm{II})$ redox couple probably played a major role in $\mathrm{As}(\mathrm{V}) / \mathrm{As}(\mathrm{III})$ inter-conversion, as suggested by the decreasing trend of measured soluble Mn concentration in the column effluent samples (Fig. 5). This observation is consistent with the redox ladder concept, in which the $\mathrm{As}(\mathrm{V}) / \mathrm{As}(\mathrm{III})$ couple falls between the $\mathrm{Mn}(\mathrm{IV}) / \mathrm{Mn}(\mathrm{II})$ and $\mathrm{Fe}(\mathrm{III}) / \mathrm{Fe}(\mathrm{II})$ redox couples; reduction of injected $\operatorname{As}(\mathrm{V})$ coincides with the oxidation of soluble $\mathrm{Mn}(\mathrm{II})$ Simultaneous measurements of these important coupled redox species may help identify the dynamic biogeochemical processes affecting As transport in geological media.

In addition to As, Fe and Mn, concentrations of other elements ( $\mathrm{K}, \mathrm{Na}, \mathrm{Ca}, \mathrm{Mg}, \mathrm{Si}, \mathrm{Al}, \mathrm{Rb}$, and $\mathrm{Ba}$ ) in the column effluents of SRS surface soil were also measured by ICP-MS. No apparent trend was no-

Table 2

Apparent distribution coefficient and inter-conversion of As species in various geological media (average \pm standard deviation, $N=3$ ).

\begin{tabular}{|c|c|c|c|c|c|c|}
\hline Sample ID & Sample location & $\mathrm{pH}$ & $\mathrm{As}(\mathrm{III}) K_{d}(\mathrm{~mL} / \mathrm{g})$ & $\mathrm{As}(\mathrm{V}) K_{d}(\mathrm{~mL} / \mathrm{g})$ & $\mathrm{As}(\mathrm{III})$ to $\mathrm{As}(\mathrm{V})$ & $\mathrm{As}(\mathrm{V})$ to $\mathrm{As}(\mathrm{III})$ \\
\hline Hanford & Richland, WA & $7.70 \pm 0.02$ & $34.4 \pm 2.80$ & $33.9 \pm 2.88$ & $2.5 \pm 0.28 \%$ & $0.14 \pm 0.02 \%$ \\
\hline SRS surface soil & Aiken, SC & $4.48 \pm 0.01$ & $1.47 \pm 0.35$ & $6012 \pm 4807$ & $0.03 \pm 0.08 \%$ & $4.5 \pm 0.46 \%$ \\
\hline SRS subsoil & Aiken, SC & $4.45 \pm 0.01$ & $178 \pm 5.72$ & $3653 \pm 1339$ & $0 \%$ & $0.03 \pm 0.23 \%$ \\
\hline SRS aquifer & Aiken, SC & $4.25 \pm 0.02$ & $115 \pm 7.45$ & $>10,000$ & $0 \%$ & $0 \%$ \\
\hline Datong DY-12 & Shanxi, China & $7.81 \pm 0.02$ & $149 \pm 5.42$ & $1060 \pm 238$ & $0.01 \pm 0.03 \%$ & $0.07 \pm 0.03 \%$ \\
\hline Datong DY-22 & Shanxi, China & $7.86 \pm 0.01$ & $275 \pm 9.95$ & $1434 \pm 552$ & $0.02 \pm 0.01 \%$ & $0.08 \pm 0.03 \%$ \\
\hline Faridpur soil & Faridpur, Bangladesh & $7.01 \pm 0.20$ & $773 \pm 38.1$ & $469 \pm 66.8$ & $0 \%$ & $0 \%$ \\
\hline
\end{tabular}




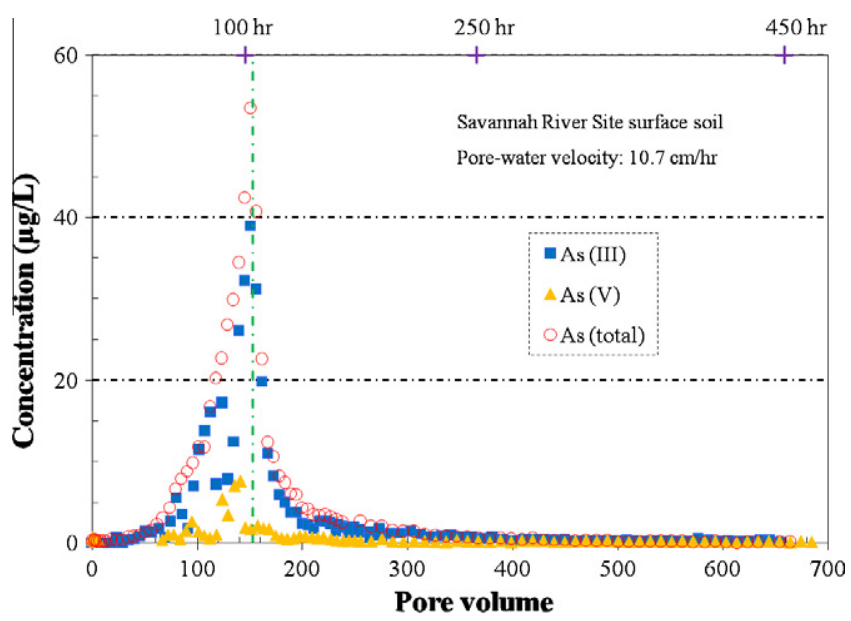

Fig. 4. Breakthrough curves of As species with the injection of $600 \mu \mathrm{g} / \mathrm{L} \mathrm{As}(\mathrm{V})$ in the SRS surface soil column test. As(III) and As(V) were simultaneously measured by LC-ICP-MS, while total As was determined by ICP-MS. The vertical dashed line indicates the location of the input pulse at 152 column pore volume when the $\mathrm{As}(\mathrm{V})$ injection was stopped to switch to flushing phase using $1 \mathrm{mM} \mathrm{Ca}\left(\mathrm{NO}_{3}\right)_{2}$.

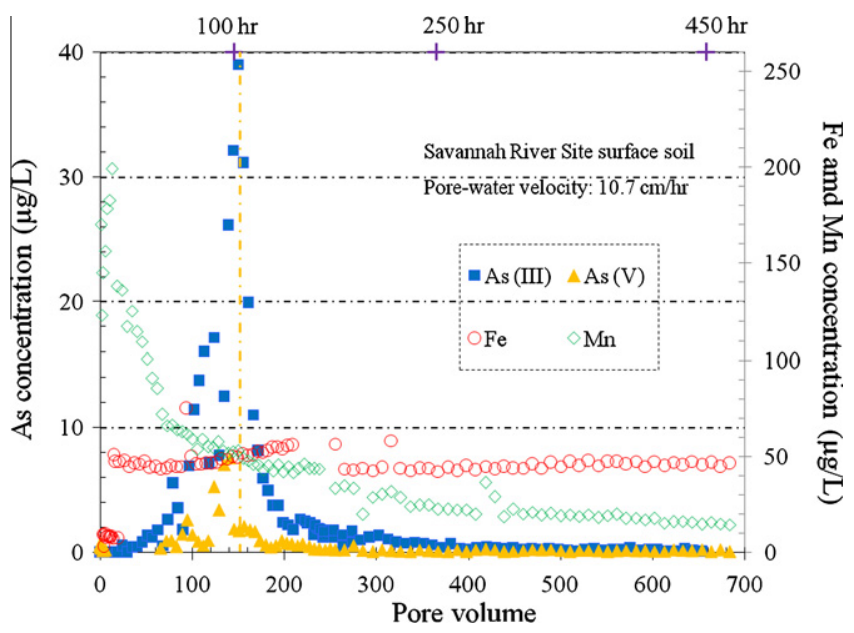

Fig. 5. Breakthrough curves for transport of injected $600 \mu \mathrm{g} / \mathrm{L} \mathrm{As}(\mathrm{V})$, produced $\mathrm{As}(\mathrm{III})$, and $\mathrm{Fe}$ and $\mathrm{Mn}$ concentration in SRS surface soil. Vertical dashed line indicates the location of the input pulse of $\mathrm{As}(\mathrm{V})$.

ticed for these elements, except for $\mathrm{Al}$ and $\mathrm{Rb}$ (Fig. 6). At about 2030 column pore volumes, the concentration of $\mathrm{Al}$ reaches a peak of $14 \mu \mathrm{g} / \mathrm{L}$ and then decreases gradually over the course of the transport experiment. The trend is similar for Rb. Furthermore, the decreasing trend of $\mathrm{Al}$ concentration coincides with that of Mn very well (Fig. 6), which suggests that both $\mathrm{Al}$ (Al oxide, Al hydroxide and aluminosilicate clay mineral) and $\mathrm{Mn}$ (Mn oxide) components in the SRS surface soil sample may have been involved in the sorption and reduction of applied $\mathrm{As}(\mathrm{V})$ in the transport studies.

As discussed above, the batch test indicated oxidation of As(III) to $\mathrm{As}(\mathrm{V})$ in Hanford sediment samples, and the apparent sorption coefficients of the As species were moderate and similar in magnitude, allowing them to break through in a column test of reasonable duration. A transport test was, therefore, conducted in which a solution of about $600 \mu \mathrm{g} / \mathrm{L} \mathrm{As}$ (III) was injected as a pulse input into a column packed with the Hanford sediment (Fig. 7). Together with the As(III) released, a modest amount [about $9 \%$ of the injected $\mathrm{As}(\mathrm{III})$ at peak concentration] of oxidized $\mathrm{As}(\mathrm{V})$ was detected in the column effluent. In addition, total As concentration as measured by ICP-MS was very similar to the sum of $\mathrm{As}(\mathrm{III})$ and

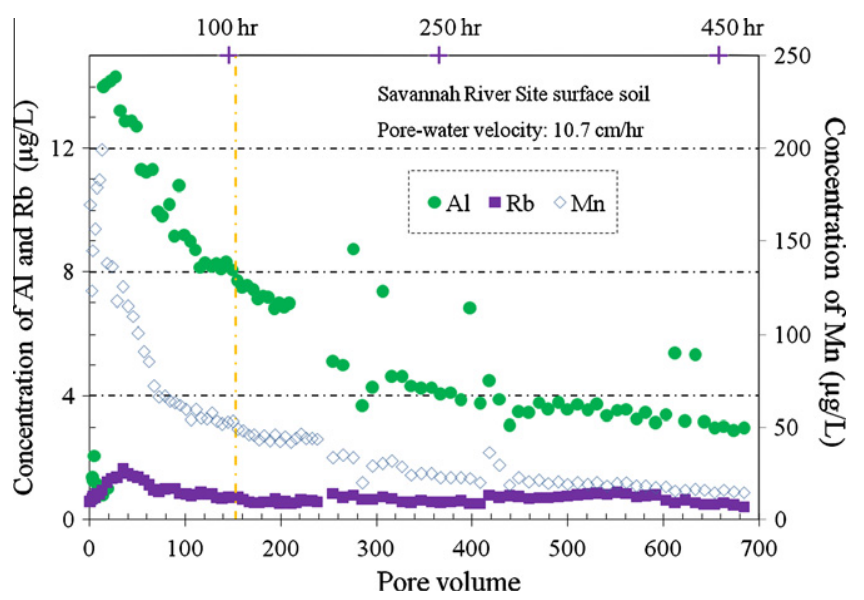

Fig. 6. Monitored concentration changes of $\mathrm{Al}, \mathrm{Mn}$ and $\mathrm{Rb}$ during transport of injected $A s(V)$ in SRS surface soil. Vertical dashed line indicates the location of the input pulse of $\mathrm{As}(\mathrm{V})$.

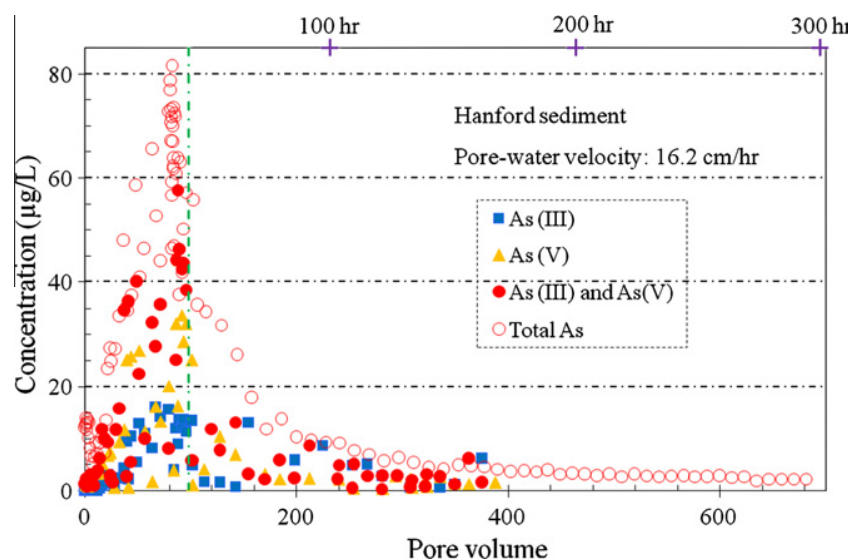

Fig. 7. Breakthrough curves of As species with the injection of $600 \mu \mathrm{g} / \mathrm{L} \mathrm{As}(\mathrm{III})$ in the Hanford sediment column test. As(III) and As(V) were measured by LC-ICP-MS while total As was determined by ICP-MS. The vertical dashed line indicates the location of the input pulse at 98 column pore volume, at a flow rate of $0.2 \mathrm{~mL} / \mathrm{min}$ for about $42 \mathrm{~h}$, when the As(III) injection was stopped to switch to flushing phase using $1 \mathrm{mM} \mathrm{Ca}\left(\mathrm{NO}_{3}\right)_{2}$.

As $(\mathrm{V})$ as determined by LC-ICP-MS, confirming the performance of both analytical approaches. Total concentrations of many other elements (K, Na, Ca, Mg, Si, Al, Fe, Mn, Rb, Sr, Ba and Th) in the column effluent of the Hanford sediment were also measured by ICPMS, and no noticeable changes in the concentration of these elements was observed.

\section{Conclusions}

Using the advanced analytical tools of LC-ICP-MS, and employing integrated batch and column experimental approaches, this study has demonstrated the coupled effects of inter-conversion and different extents of sorption of As species as they interact with different geologic media. For example, As(III) oxidation was observed in the Hanford sediment, while $\mathrm{As}(\mathrm{V})$ reduction was found in SRS surface soil. The work has also yielded information on distribution coefficients, as needed for transport studies, for both $\mathrm{As}(\mathrm{V})$ and As(III) in the SRS and Hanford materials, and in the Datong Basin sediments and the surface soil of the Faridpur district of Bangladesh. The results will help expand understanding of As release in the subsurface, and of the processes controlling groundwater enrichment by As. 


\section{Acknowledgments}

This work was financially supported by the University of Texas at Arlington.

\section{References}

Ackermann, J., Vetterlein, D., Tanneberg, H., Neue, H.U., Mattusch, J., Jahn, R., 2008 Speciation of arsenic under dynamic conditions. Eng. Life Sci. 8, 589-597.

American Society for Testing and Materials (ASTM), 1998. Standard Test Method for 24-hour Batch-type Measurement of Contaminant Sorption by Soils and Sediments (D4646-87). Annual Book of ASTM Standards. Philadelphia, PA, American Society for Testing and Materials. 04.08:44-47.

Bednar, A.J., Garbarino, J.R., Ranville, J.F., Wildeman, T.R., 2002. Preserving the distribution of inorganic arsenic species in groundwater and acid mine drainage samples. Environ. Sci. Technol. 36, 2213-2218.

Belzile, N., Tessier, A., 1990. Interactions between arsenic and iron oxyhydroxides in lacustrine sediments. Geochim. Cosmochim. Acta 54, 103-109.

British Geological Survey (BGS), Bangladesh Department Public Health Engineering 2001. Arsenic Contamination of Groundwater in Bangladesh. BGS Technical Report WC/00/19. Kinniburg, D.G., Smedley, P.L. (Eds.), British Geological Survey, Keyworth, UK.

Bissen, M., Frimmel, F.H., 2003. Arsenic - a review. Part 1: occurrence, toxicity, speciation, mobility. Acta Hydroch. Hydrob. 31, 9-18.

Cancès, B., Juillot, F., Morin, G., Laperche, V., Alvarez, L., Proux, O., Hazemann, J.-L., Brown Jr, G.E., Calas, G., 2005. XAS evidence of As(V) association with iron oxyhydroxides in a contaminated soil at a former arsenical pesticide processing plant. Environ. Sci. Technol. 39, 9398-9405.

Charlet, L., Polya, D.A., 2006. Arsenic hazard in shallow reducing groundwaters in southern Asia. Elements 2, 91-96.

Chen, S.L., Yeh, S.J., Yang, M.H., Lin, T.H., 1995. Trace element concentration and arsenic speciation in the well water of a Taiwan area with endemic Blackfoot disease. Biol. Trace Elem. Res. 48, 263-274.

Choi, S., O’Day, P.A., Hering, J.G., 2009. Natural attenuation of arsenic by sediment sorption and oxidation. Environ. Sci. Technol. 43, 4253-4259.

Cullen, W.R., Reimer, K.J., 1989. Arsenic speciation in the environment. Chem. Rev. 89, 713-764.

D’Ilio, S., Violante, N., Di Gregorio, M., Senofonte, O., Petrucci, F., 2006. Simultaneous quantification of 17 trace elements in blood by dynamic reaction cell inductively coupled plasma mass spectrometry (DRC-ICP-MS) equipped with a high-efficiency sample introduction system. Anal. Chim. Acta 579, 202-208.

Dixit, S., Hering, J.G., 2003. Comparison of arsenic(v) and arsenic(iii) sorption onto iron oxide minerals: implications for arsenic mobility. Environ. Sci. Technol. 37, 4182-4189.

Dixit, S., Hering, J.G., 2006. Sorption of Fe(II) and As(III) on goethite in single- and dual-sorbate systems. Chem. Geol. 228, 6-15.

Fendorf, S., Kocar, B.D., 2009. Biogeochemical processes controlling the fate and transport of arsenic implications for South and Southeast Asia. Adv. Agron. 04 (104), 137-164.

Gallagher, P.A., Schwegel, C.A., Wei, X.Y., Creed, J.T., 2001. Speciation and preservation of inorganic arsenic in drinking water sources using EDTA with IC separation and ICP-MS detection. J. Environ. Monitor. 3, 371-376.

Garbarino, J.R., Bednar, A.J., Burkhardt, M.R., 2002. Methods of Analysis by the US Geological Survey National Water Quality Laboratory-Arsenic Speciation in Natural Water Samples using Laboratory and Field Methods. US Geol. Surv. Water-Resour. Invest. Rep. 02-4144.

Gault, A.G., Jana, J., Chakraborty, S., Mukherjee, P., Sarkar, M., Nath, B., Polya, D.A Chatterjee, D., 2005. Preservation strategies for inorganic arsenic species in high iron, low Eh groundwater from West Bengal, India. Anal. Bioanal. Chem. 381 347-353.

Goldberg, S., 2002. Competitive adsorption of arsenate and arsenite on oxide and clay minerals. Soil Sci. Soc. Am. J. 66, 413-421.

Guo, H.M., Wang, Y.X., Shpeizer, G.M., Yan, S.L., 2003. Natural occurrence of arsenic in shallow groundwater, Shanyin, Datong Basin, China. J. Environ. Sci. Health Part a - Toxic/Hazard. Subst. Environ. Eng. 38, 2565-2580.

Hu, Q., Brusseau, M.L., 1996. Transport of rate-limited sorbing solutes in an aggregated porous medium: a multiprocess non-ideality approach. J. Contam. Hydrol. 24, 53-73.
Hu, Q., Zhao, P.H., Moran, J.E., Seaman, J.C., 2005. Sorption and transport of iodine species in sediments from the Savannah River and Hanford Sites. J. Contam. Hydrol. 78, 185-205.

Inskeep, W.P., McDermott, T.R., Fendorf, S., 2002. Arsenic (V)/(III) cycling in soils and natural waters: chemical and microbiological processes. In: Frankenberger, W.T., Jr. (Ed.), Environmental Chemistry of Arsenic. Marcel Dekker, New York, pp. 183-215.

Kawabata, K., Kishi, Y., 2003. DRC-ICP-MS analysis of various chemicals used in the semiconductor industry (Reprinted with permission from the Semiconductor Pure Water \& Chemicals Conference 2001). Atom. Spectrosc. 24, 66-72.

Lenoble, V., Bouras, O., Deluchat, V., Serpaud, B., Bollinger, J.-C., 2002. Arsenic adsorption onto pillared clays and iron oxides. J. Colloid Interf. Sci. 255, 52-58.

Manning, B.A., Goldberg, S., 1997. Adsorption and stability of arsenic(III) at clay mineral-water interface. Environ. Sci. Technol. 31, 2005-2011.

Masue, Y., Loeppert, R.H., Kramer, T.A., 2007. Arsenate and arsenite adsorption and desorption behavior on coprecipitated aluminum: iron hydroxides. Environ. Sci. Technol. 41, 837-842.

McCleskey, R.B., Nordstrom, D.K., Maest, A.S., 2004. Preservation of water samples for arsenic(III/V) determinations: an evaluation of the literature and new analytical results. Appl. Geochem. 19, 995-1009.

Morin, G., Calas, G., 2006. Arsenic in soils, mine tailings, and former industrial sites. Elements 2, 97-101.

Nickson, R.T., McArthur, J.M., Burgess, W.G., Ahmed, K.H., Ravenscroft, P., Rahman, M.W., 1998. Arsenic poisoning of Bangladesh groundwater. Nature 395, 338.

Nordstrom, D.K., 2002. Public health - worldwide occurrences of arsenic in ground water. Science 296, 2143-2145.

National Research Council (NRC), 1999. Arsenic in Drinking Water. National Academy Press, Washington, DC.

O'Day, P.A., Vlassopoulos, D., Root, R., Rivera, N., 2004. The influence of sulfur and iron on dissolved arsenic concentrations in the shallow subsurface under changing redox conditions. Proc. Natl Acad. Sci. USA 101, 17303-17308.

Onken, B.M., Adriano, D.C., 1997. Arsenic availability in soil with time under saturated and subsaturated conditions. Soil Sci. Soc. Am. J. 61, 746-752.

O’Reilly, S.E., Strawn, D.G., Sparks, D.L., 2001. Residence time effects on arsenate adsorption/desorption mechanisms on goethite. Soil Sci. Soc. Am. J. 65, 67-77.

Polya, D., Charlet, L., 2009. Environmental science. Rising arsenic risk? Nat. Geosci. 2, 383-384.

Polya, D.A., Lythgoe, P.R., Abou-Shakra, F., Gault, A.G., Brydie, J.R., Webster, J.G., Brown, K.L., Nimfopoulos, M.K., Michailidis, K.M., 2003. IC-ICP-MS and IC-ICPHEX-MS determination of arsenic speciation in surface and groundwaters: preservation and analytical issues. Mineral. Mag. 67, 247-262.

Reuter, W., Davidowski, L., Neubauer, K., 2003. Speciation of five arsenic compounds in urine by HPLC/ICP-MS. Application Note of Perkin Elmer Life and Analytical Sciences, Shelton, $\mathrm{CT}$.

Saeki, K., 2008. The comparison of arsenite and arsenate adsorption on an andosol. Soil Sci. 173, 248-256.

Sharma, V.K., Sohn, M., 2009. Aquatic arsenic: toxicity, speciation, transformations, and remediation. Environ. Int. 35, 743-759.

Smedley, P.L., Kinniburgh, D.G., 2002. A review of the source, behaviour and distribution of arsenic in natural waters. Appl. Geochem. 17, 517-568.

Stucki, J.W., Bailey, G.W., Gan, H.M., 1996. Oxidation-reduction mechanisms in iron-bearing phyllosilicates. Appl. Clay Sci. 10, 417-430.

Sun, G.-X., Williams, P.N., Carey, A.-M., Zhu, Y.-G., Deacon, C., Raab, A., Feldmann, J., Islam, R.M., Meharg, A.A., 2008. Inorganic arsenic in rice bran and its products are an order of magnitude higher than in bulk grain. Environ. Sci. Technol. 42, 7542-7546

Tufano, K.J., Fendorf, S., 2008. Confounding impacts of iron reduction on arsenic retention. Environ. Sci. Technol. 42, 4777-4783.

Vanhaecke, F., Balcaen, L., De Wannemacker, G., Moens, L., 2002. Capabilities of inductively coupled plasma mass spectrometry for the measurement of $\mathrm{Fe}$ isotope ratios. J. Anal. Atom. Specros. 17, 933-943.

Vaughan, D.J., 2006. Arsenic. Elements 2, 71-75.

Williams, L.E., Barnett, M.O., Kramer, T.A., Melville, J.G., 2003. Adsorption and transport of arsenic(V) in experimental subsurface systems. J. Environ. Qual. 32, 841-850.

Xie, X., Wang, Y., Su, C., Liu, H., Duan, M., Xie, Z., 2008. Arsenic mobilization in shallow aquifers of Datong Basin: hydrochemical and mineralogical evidences. J. Geochem. Explor. 98, 107-115.

Yang, S.X., 2008. Research on arsenic distribution and origin in groundwater in Datong Basin. Master Thesis, Beijing Normal University, Beijing, China, Shanxi Province. 